\author{
Matgorzata Pietrzak \\ Uniwersytet Jagielloński, Kraków, Polska - Jagiellonian University in Krakow, Poland \\ EWELINA SOBOCHA \\ Uniwersytet Pedagogiczny w Krakowie, Polska - Pedagogical University of Krakow, Poland
}

\title{
Kompetencje społeczne a możliwości aktywizacji zawodowej osób z niepełnosprawnością intelektualną na otwartym rynku pracy
}

\section{Social Competences for Professional Activation on the Open Labour Market of People with Intellectual Disabilities}

\begin{abstract}
Streszczenie: $\mathrm{W}$ artykule wymieniono przyczyny i skutki niskiego poziomu aktywności zawodowej osób z niepełnosprawnością intelektualną (NI). Na podstawie sondażu przeprowadzonego z pracownikami otwartego rynku w Krakowie w 2018 r. zidentyfikowano bariery i szanse współpracy zawodowej osób w normie intelektualnej i osób z niepełnosprawnością intelektualną. Zaproponowano model edukacji i kontaktu młodzieży w normie intelektualnej z młodzieżą z NI, zwiększający szanse na otwarcie się rynku pracy na zatrudnianie osób z NI. Wykorzystując obserwację uczestniczącą zajęć przedsiębiorczości we wspólnej grupie, zaproponowano podejście integracyjne, tzw. inkluzji społecznej, w którym zasadniczą rolę podczas lekcji pełni trening kontaktów międzyludzkich (poznawczo-behawioralny) oraz nauczanie praktyczne - zewnętrzne (w rzeczywistych sytuacjach). Obserwacji poddani byli uczniowie ze Specjalnego Ośrodka Szkolno-Wychowawczego nr 3 w Krakowie oraz studenci Instytutu Geografii i Gospodarki Przestrzennej Uniwersytetu Jagiellońskiego.
\end{abstract}

\begin{abstract}
The article lists the causes and effects of the low level of professional activity of people with intellectual disabilities (NI). On the basis of a survey with service employees, identified were barriers and chances of professional cooperation between people in the intellectual norm and people with intellectual disability. The paper presents a new model of education of young people with intellectual disabilities, to improve employment opportunities. Using the participant observation of entrepreneurship activities in a joint group, an integrative approach was proposed, i.e. social inclusion, in which training in interpersonal contacts (cognitive-behavioural) and practical teaching - external (in real situations) - play an essential role during the lesson. The study was conducted with the participation of middle school students with moderate and significant intellectual disability from the Special Education and Training Centre No 3 in Krakow (SOSW 3). Co-participants in the study were students from the Institute of Geography and Spatial Management of the Jagiellonian University.
\end{abstract}

Słowa kluczowe: aktywizacja zawodowa; edukacja włączająca; inkluzja społeczna; kompetencje społeczne; niepełnosprawność intelektualna; rynek pracy; zdolność do pracy 
Keywords: inclusive education; labour market; mental disorders; professional activation; social competences; social inclusion; work ability

Otrzymano: 18 stycznia 2019

Received: 18 January 2019

Zaakceptowano: 12 sierpnia 2019

Accepted: 12 August 2019

\section{Sugerowana cytacja/Suggested citation:}

Pietrzak, M., Sobocha, E. (2019). Kompetencje społeczne a możliwości aktywizacji zawodowej osób z niepełnosprawnością intelektualną na otwartym rynku pracy. Przedsiębiorczość - Edukacja [Entrepreneurship - Education], 15(2), 95-105. doi: 10.24917/20833296.152.7

„Praca w znaczeniu przedmiotowym [...] musi być podpo-
rządkowana godności człowieka, podmiotowi pracy, a nie
korzyści ekonomicznej”.
Jan Paweł II, Laborem Exercens

Wstęp

Dynamiczne zmiany społeczne i cywilizacyjne obligują jednostkę do odnalezienia swojego miejsca w otaczającym świecie, dążenia do uzyskania autonomii, samorealizacji oraz radości z własnego istnienia. Zmiany te dotyczą również osób z niepełnosprawnościami, które muszą podjąć próbę sprostania zróżnicowanym wymogom (Zaorska, 2017).

W 2017 r. w Polsce współczynnik aktywności zawodowej osób sprawnych w wieku produkcyjnym wynosił $79,8 \%$, wskaźnik zatrudnienia $75,9 \%$, a stopa bezrobocia $4,9 \%$. Wartości tych samych wskaźników dla osób niepełnosprawnych w wieku produkcyjnym wynosiły odpowiednio: 28,9\%, 26,3\% oraz 9,3\%. W latach 2008-2017 najmniejszą różnicę między wskaźnikiem zatrudnienia osób sprawnych a niepełnosprawnych w wieku produkcyjnym wynoszącą 46,3 pp. zanotowano w 2012 r., największą w roku 2016 - 50,8 pp. Wskaźnik zatrudnienia osób niepełnosprawnych w wieku produkcyjnym w badanych latach wzrósł z poziomu 20,8\% do 26,3\% (Osoby niepełnosprawne..., 2018).

Istotnym problemem społecznym jest niski poziom aktywności zawodowej osób z niepełnosprawnością intelektualną (NI) pomimo, że od 2004 r. pojawiły się w polskim systemie oświaty szkoły przysposabiające do pracy (SPP). Z badań GUS-u prowadzonych w 2012 r. wynika, że jedynie 14,7\% osób z niepełnosprawnością intelektualną w wieku powyżej 15 lat - osób mogących pracować zawodowo - znalazło zatrudnienie (Urbańska, 2013). Niski współczynnik aktywności zawodowej osób niepełnosprawnych stanowi jedną z przyczyn wykluczenia społecznego tej grupy osób (Cieślik, 2014). Wskaźnik zatrudnienia osób niepełnosprawnych w Polsce jest jednym z najniższych w Europie (Rymsza, 2013). W raporcie PFRON-u wymieniono następujące przyczyny ich niskiej aktywności zawodowej: postawy osoby niepełnosprawnej, postawy pracodawcy, warunki środowiska pracy i otoczenia zewnętrznego (Barczyński, Radecki, 2008). Ważnym czynnikiem jest również mała efektywność działań prowadzonych przez organy administracji rządowej, organy jednostek samorządu terytorialnego i Państwowy Fundusz Rehabilitacji Osób Niepełnosprawnych (Rymsza, 2013). Brak jest dokładnych danych dotyczących osób niepełnosprawnych intelektualnie na rynku pracy. Bierność zawodowa tej grupy wynika również z faktu, że równolegle z orzeczeniem niepełnosprawności intelektualnej 
w stopniu umiarkowanym i znacznym wydawany jest dokument o niezdolności do pracy. Redukuje to zatrudnienie, a pobieranie renty uszczupla zarobki.

Choć trudno jest oszacować, jaka część osób otrzymująca zabezpieczenia socjalne jest zainteresowana wejściem na rynek pracy, to badania wskazują, że osoby z niepełnosprawnością intelektualną dobrze sprawdzają się na stanowiskach pomocniczych lub w pracy precyzyjnej (np. pomoc sprzedawcy, pomoc kuchenna, pokojowa, pracownik gospodarczy, pracownik produkcji, osoba sprzątająca). Koordynator Centrum DZWONI, A. Mstowski (2019), charakteryzuje osoby z NI jako rzetelne, dokładne, zmotywowane do pracy. Istnieje więc możliwość wykorzystania czynników pozaintelektualnych, takich jak osobowość i motywacja w środowisku pracy (Kościelska, 1984, 1995).

Obecnie nauczanie przedmiotów zawodowych uczniów z niepełnosprawnością intelektualną w stopniu umiarkowanym lub znacznym opiera się na indywidualnych programach edukacyjnych obejmujących kształtowanie właściwych postaw wobec zatrudnienia oraz nabywanie umiejętności wykonywania określonych zajęć na otwartym lub chronionym rynku pracy (GUS, 2017). Ważnym celem pracy zawodowej osób niepełnosprawnych intelektualnie jest włączenie ich w życie społeczne. Podjęcie pracy oznacza dla takich osób polepszenie sytuacji bytowej, zwiększenie poczucia własnej wartości, rozwój osobowości, wzmacnianie kompetencji społecznych. Pomimo edukacji w szkołach przyspasabiających do pracy większość osób niepełnosprawnych intelektualnie jest bierna zawodowo. Pozostają im zajęcia w ramach warsztatów terapii zajęciowej, co nie daje szans na integrację społeczną i czynne włączenie się w życie społeczne w pełnym wymiarze. Wiele międzynarodowych badań wskazuje na konieczność podniesienia kultury organizacyjnej firm i przedsiębiorstw, które kształtują wartości i charakter miejsca pracy, zmian w ustawodawstwie i polityce społecznej, a także w edukacji celem likwidowania stereotypów i uprzedzeń (Atlas dobrych praktyk..., 2011; Burgea, Ouellette-Kuntz, Lysagh, 2007; Diament, 2015; Vornholt i in., 2018; Yang, 2016).

\section{Cel i zakres działań}

Niniejsza praca koncentruje się na problemie edukacji włączającej i wspomaganej prowadzącej do aktywizacji zawodowej osób niepełnosprawnych, co przeciwdziała wykluczeniu społecznemu tej grupy. Przedyskutowano nową drogę otwarcia się rynku pracy na zatrudnianie osób z NI przez wczesną edukację i kontakt młodzieży w normie intelektualnej $\mathrm{z}$ młodzieżą z NI.

W pracy przyjęto założenie, że przedsiębiorczość głównie opiera się na cechach charakteru - odwadze, przekonaniu, pewności siebie, wierze w pomyślność, wytrwałości, pasji, a tych przymiotów nie sposób przekazać na teoretycznych zajęciach szkolnych lub izolowanych treningach w szkołach przyspasabiających do pracy. Ważnym w kształceniu jest bezpośredni kontakt i poznanie zalet osób niepełnosprawnych przez osoby w normie intelektualnej. Obie grupy rozwijają kompetencje społeczne przez praktyczne działanie w realnych sytuacjach. Ponadto przyjęto, że wspólne działania otwierają na nowość i inność.

Kształcenie młodzieży w szkołach publicznych zakłada, że młodzi ludzie z wykształceniem w zakresie przedsiębiorczości chętniej zakładają własne firmy, są bardziej ambitni (Entrepreneurship education, 2018). Wykazano, że 20\% uczniów, którzy uczestniczą w programie miniprzedsiębiorczości w szkole średniej, otworzy później własną firmę tj. pięć razy więcej niż w populacji ogólnej (Entrepreneurship education, 2019). Z drugiej 
jednak strony badania wskazują, że nauczanie przedsiębiorczości oparte na wiedzy nie jest skuteczne, gdyż nie jest zorientowane na działanie (Yang, 2016). Istnieją zatem różne podejścia do kształcenia przedsiębiorczości młodzieży w normie intelektualnej, jak i młodych ludzi z NI. Jak podkreśla D. Piróg (2015), człowieka przedsiębiorczego powinny cechować wysokie kompetencje interpersonalne, w tym dostrzeganie potrzeb innych osób i wrażliwość na te potrzeby. Niestety, w obu wymienionych modelach kształcenia przedsiębiorczości nie ma miejsca na wzajemne poznanie, prowadzące do odkrywania swoich zalet i możliwości twórczych.

Pilotażowe działania edukacyjne w obszarze przedsiębiorczości zainicjowane zostały podczas współpracy Specjalnego Ośrodka Szkolno-Wychowawczego nr 3 w Krakowie i Instytutu Geografii i Gospodarki Przestrzennej Uniwersytetu Jagiellońskiego. Przed podjęciem działań edukacyjnych zainicjowano rozpoznanie postaw pracodawców - jednego z czterech głównych czynników niskiej aktywności zawodowej osób niepełnosprawnych. Wykorzystano sondaż (wywiad ankieterski osobisty), który przeprowadzono na terenie miasta Krakowa w 2018 r. Celem sondażu było poznanie postaw i opinii pracodawców, pracowników i osób z NI zatrudnionych w jednym środowisku pracy. Podjęto próbę identyfikacji oraz charakterystyki barier i szans współpracy zawodowej osób w normie intelektualnej i osób z niepełnosprawnością intelektualną. Wywiady przeprowadzono z menedżerami, właścicielami firm, kierownikami sklepów i zakładów usługowych oraz pracownikami (łącznie rozmawiano z 20 osobami). Sondaże przeprowadzono w sklepach różnych branż, jednostkach usług materialnych, niematerialnych i dla biznesu (podział wg Europejskiej Klasyfikacji Działalności). Były to: sklepy budowlane, sklep ogrodniczy, salony fryzjerskie, gabinety kosmetyczne, sklep zoologiczny, cukiernie, piekarnia, sklepy z odzieżą, kawiarnie, sklepy spożywcze, budka $\mathrm{z}$ warzywami, drogerie.

Wnioski z wywiadów posłużyły wskazaniu na pozytywne i negatywne cechy istniejących sposobów kształcenia. W rezultacie zaproponowano model edukacji przedsiębiorczości, którego istotą jest edukacja włączająca (inkluzja społeczna) młodzieży pełnoi niepełnosprawnej. Obserwację uczestniczącą zajęć prowadzono celem analizy interakcji w grupie i oceny skuteczności edukacji przez warsztaty z kształtowania postawy przedsiębiorczej. W badaniu uczestniczyło 7 uczniów z NI w stopniu umiarkowanym i znacznym ze Specjalnego Ośrodka Szkolno-Wychowawczego nr 3 w Krakowie. Uczestnicy badania to gimnazjaliści w wieku od 15 do 19 lat, 2 chłopców i 5 dziewcząt. Ze strony Instytutu Geografii i Gospodarki Przestrzennej Uniwersytetu Jagiellońskiego współuczestnikami badania było 15 studentów kursu dydaktycznego. Zajęcia odbywały się na terenie SOSW 3, Kampusu 600-lecia Odnowienia Uniwersytetu Jagiellońskiego oraz w przestrzeni społecznej. Obserwacje prowadzono w latach 2017/2018 i 2018/2019.

Z uwagi na specyficzne funkcjonowanie osób z NI i brak standardowych modeli kształcenia przedsiębiorczości tej grupy, w badaniach zastosowano metodę rozszerzonych przypadków. W sytuacjach nietypowych pozwala ona na najlepszą analizę zjawisk, odkrywanie wszystkich przejawów rozbieżności obserwacji z istniejącymi teoriami, dogłębne ich wyjaśnienie, a następnie - modyfikowanie istniejących teorii (Babbie, 2007).

Dyskusja nad wynikami

Zrozumienie opinii publicznej jest ważnym czynnikiem w budowaniu skutecznych programów promujących zintegrowane zatrudnienie. Sondaż pokazał słabe i mocne 
edukacji przedsiębiorczości i przygotowania zawodowego w zatrudniania osób z NI. Uczniowie z NI w stopniu lekkim kończą szkoły zawodowe i mają szanse na zatrudnienie, w przeciwieństwie do osób NI w stopniu umiarkowanym, które kończą SPP. Nie kończą one szkół z przygotowaniem zawodowym, a jedynie nabywają pewne umiejętności zawodowe, przeważnie związane z zawodem pomocniczym, np. pomocnika ogrodnika, kucharza, pracownika biurowego (nie są to samodzielne zawody). Istnieją projekty przygotowujące osoby z NI do działalności gospodarczej np. Centrum Dzwoni, Chrześcijańskie Stowarzyszenie Osób Niepełnosprawnych Ich Rodzin i Przyjaciół „Ognisko”. Jednakowo ważne są szkolenia pracodawców, współpracowników, gdyż szkoły integracyjne nie przyczyniają się do podniesienia ogólnego poziomu wiedzy na temat funkcjonowania osób z NI.

W wyniku przeprowadzonych ankieterskich wywiadów osobistych w Krakowie w 2018 r. sformułowano następujące wnioski:

1. Polityka firmy decyduje o zatrudnianiu osób niepełnosprawnych, w tym istotną rolę odgrywają administracyjne rozwiązania (rządowe przepisy).

2. Indywidualni właściciele są otwarci na zatrudnianie osób niepełnosprawnych, w ich ocenie nie wpływa to na jakość, organizację, wizerunek firmy oraz na relacje interpersonalne w zespole.

3. O otwartości postaw pracowników wszystkich szczebli decydują wiedza oraz własne doświadczenia w kontakcie z osobami niepełnosprawnymi.

4. Starsze osoby $z$ większym dystansem podchodzą do samodzielnie wykonanych przez osoby z NI prac i ich kontaktów z klientami (nadmierna opiekuńczość).

5. W ocenie ankietowanych „społeczeństwo nie dojrzało do kontaktu z osobami niepełnosprawnymi”, wszyscy podkreślali potrzebę szkoleń dotyczących komunikacji i relacji z osobami niepełnosprawnymi.

Z uwagi na liczbę przeprowadzonych rozmów analiza ankieterskich wywiadów osobistych miała charakter jakościowy. Wartością ankiety było wnikliwe poznanie perspektywy pracowników otwartego rynku pracy na współpracę z osobami z NI.

Sondaż potwierdził rezultaty badań nad aktywnością zawodową osób niepełnosprawnych. Ograniczenia wykonywanej pracy wynikają głównie z trudności w komunikowaniu się, tj. rozumieniu i byciu rozumianym (85\% osób mających tego typu trudności stwierdziło ograniczenie rodzaju pracy), zapamiętywaniu, koncentrowaniu się (78\% osób wskazało na ten typ problemu) (GUS, 2012). Poziom wykształcenia zwiększa pewność siebie osób z dolegliwościami zdrowotnymi, co zwiększa możliwości poradzenia sobie z wybranym rodzajem pracy (Ministerstwo Rodziny, Pracy i Polityki Społecznej, 2018). W badaniach naukowców kanadyjskich (Burgea, Ouellette-Kuntz, Lysagh, 2007) stwierdzono, że największe problemy z zatrudnianiem osób z NI wynikają z niedoskonałości programów szkolenia zawodowego w celu przygotowania ich do pracy (na ten czynnik wskazało $71,7 \%$ respondentów), z przekonania pracodawców o braku potrzebnych kwalifikacji u osób z NI (69,2\% respondentów), negatywnego nastawienia pracowników (stereotypów postrzegania osób NI) (53,4\% respondentów). Jak wynika z tych samych badań, 87\% respondentów uważa, że zatrudnienie osoby z niepełnosprawnością intelektualną nie wpłynęłyby negatywnie na wizerunek miejsc pracy, niższą wydajność, zwiększoną wypadkowość (Burgea, Ouellette-Kuntz, Lysagh, 2007).

Co czwarta badana osoba $\mathrm{z}$ NI wskazuje na potrzebę korzystania z pomocy innych osób. W państwach UE, na otwartym rynku pracy, zatrudnienie jest wspomagane przez 
„trenera pracy wspomaganej”. Trener pracy pomaga osobie niepełnosprawnej intelektualnie znaleźć pracę i nauczyć się dobrze wykonywać swoje obowiązki (Abramowska, Tłoczowska, 2007). W Polsce jest mało trenerów pracy, niski poziom wiedzy pracodawców i pracowników dotyczącej współpracy z osobami z NI oraz brak odpowiednich przepisów (Wapiennik, 2005).

Dość dużym zainteresowaniem spotyka się część projektów unijnych, które mają na celu przygotowanie osób niepełnosprawnych do aktywnego uczestnictwa na rynku pracy. Dzięki tym działaniom realizuje się zatrudnienie wspomagane, które szczególnie istotne jest, gdy dotyczy osób z niepełnosprawnością intelektualną. Zatrudnienie wspomagane to „dostarczenie wsparcia osobom $\mathrm{z}$ niepełnosprawnością oraz innym grupom osób wykluczonych, mającego na celu zapewnienie im i utrzymanie płatnego zatrudnienia na otwartym rynku pracy" (Europejska Unia Zatrudnienia Wspomaganego..., 2013: 16).

\section{Refleksja z zajęć przedsiębiorczości}

Analiza indywidualnych przypadków i obserwacja uczestnicząca współdziałającej grupy ze Specjalnego Ośrodka Szkolno-Wychowawczego nr 3 w Krakowie i Instytutu Geografii i Gospodarki Przestrzennej Uniwersytetu Jagiellońskiego pozwoliły poznać indywidulane opinie o relacjach w zespole. Znaczącym momentem spotkań była sytuacja, w której wszyscy uczestnicy zdali sobie sprawę ze wspólnych zainteresowań i sposobów funkcjonowania, co wzmocniło wzajemne relacje, otwartość i zrozumienie. Uczniowie i uczennice z NI podkreślali ważność zajęć, ponieważ studenci skupiali na nich uwagę, zadawali pytania, pomagali w pracy, angażowali się we współpracę oraz wyrażali swoje uznanie i entuzjazm z wykonywanych działań. W wypowiedziach uczniów i uczennic z NI pojawiały się takie stwierdzenia, jak: „wspólne zajęcia powodują, że chce nam się więcej”, „chcemy pracować więcej”, „poznajemy ciekawe i nowe miejsca”, „lubią nas słuchać, gdy mówimy o sobie”, „lubimy, kiedy studenci się przyłączają do naszej pracy”, „chcemy pokazać się z dobrej strony”, „„łuchają, gdy mówimy o sobie/zadają nam pytania”, „możemy rozmawiać na różne tematy”.

\section{Propozycja działań edukacyjnych}

Prezentowana poniżej idea działań edukacyjnych dedykowana jest osobom z NI, które szczególnie są narażone na wykluczenie społeczne czy zawodowe. Proponowane zajęcia to efekt współpracy Specjalnego Ośrodka Szkolno-Wychowawczego nr 3 w Krakowie i Instytutu Geografii i Gospodarki Przestrzennej Uniwersytetu Jagiellońskiego. Opisana koncepcja zajęć przedsiębiorczości zawiera założenia inkluzji społecznej.

Inkluzja społeczna jest przeciwieństwem wykluczenia społecznego. Jej priorytetem jest wyrównywanie szans, przeciwdziałanie wykluczeniu społecznemu oraz wsparcie jednostek zagrożonych wykluczaniem. Celem inkluzji społecznej jest dążenie do zapewnienia osobom zagrożonym wykluczaniem zasobów dających ograniczenie pełnego uczestnictwa w życiu ekonomicznym, społecznym oraz publicznym.

Proces inkluzji daje możliwość oraz zasoby warunkujące pełne uczestnictwo w życiu ekonomicznym, społecznym i kulturalnym. Pozwala zachować standardy życia na poziomie określanym jako normalny w danym społeczeństwie (Szafranek, Halicki, 2016).

Sukces inkluzji zależy od zgrania potrzeb pracodawcy z potrzebami pracownika. Według J. Jerga (specjalista od inkluzji społecznej, socjolog), inkluzja zaczyna się w naszych 
głowach (za: Szafranek, Halicki, 2016). Tym bardziej warto zmienić swoje nastawienie do osób z niepełnosprawnością, wpływać na zmiany postaw ludzi w naszym otoczeniu, doskonalić model zatrudnienia wspomaganego i edukacji włączającej.

Celem zaproponowanych zajęć edukacyjnych z przedsiębiorczości było wypracowanie umiejętności przydatnych w aktywności zawodowej. Kompetencje społeczne przydatne na otwartym rynku pracy, które miał nabyć w ich trakcie uczeń, to:

- potrafi się komunikować,

- stosuje się do reguł i uzgodnień,

- kontroluje własny stres w efektywny sposób,

- integruje się z zespołem i wypracowuje pozytywne relacje ze współpracownikami, potrafi zachować się w sposób towarzysko akceptowalny (Hamond, Haccou, 2013).

Podczas zajęć dla uczniów i uczennic z SOSW nr 3 wspierano następujące sposoby pracy: życzliwa pomoc, cierpliwość, bezwzględna akceptacja osoby, dobre nastawienie, nauczanie praktyczne. Podczas pracy studentów IGiGP UJ z osobami z NI skuteczną edukacją dla wszystkich było wykorzystanie treningów społecznych i działanie przez doświadczanie. Sposoby pracy wspólne dla obu grup wykorzystywały trening kontaktów międzyludzkich (poznawczo-behawioralny) oraz nauczanie praktyczne - zewnętrzne (w rzeczywistych sytuacjach).

Proponowany model zajęć edukacyjnych z przedsiębiorczości zakładał realizację trzech etapów (rycina 1).

\section{ETAP: Zajęcia w szkole - trening umiejętności społecznych}

Początkowo osoby z NI miały trudności w dostosowaniu się do reguł odpowiednich dla danych okoliczności. Potrzebowały czasu, by zrozumieć sytuację społeczną, aby w niej się odnaleźć. W związku z tym wymagały pomocy w zakresie właściwego reagowania. Dlatego celem pierwszego etapu zajęć było rozwijanie komunikacji interpersonalnej, doskonalenie samokontroli, budzenie świadomości własnych celów i cech, rozumienie norm wspólnotowych, dopasowanie właściwych zachowań do różnych zachowań społecznych. Na tym etapie przyświecała zasada wskazana przez papieża Leon XIII „pomocniczości we wspólnocie” (Ryś, 2018).

\section{ETAP: Zajęcia w szkole - trening współpracy, podejmowanie działań}

Istotą drugiego etapu było wzajemne zadawanie właściwych pytań, rozwijanie umiejętności „wyłuskiwania” inicjatywy niepełnosprawnego przez poddawanie jego pomysłów realizacji, podmiotowe traktowanie osób, podczas którego student był przewodnikiem udzielającym wsparcia rówieśnikowi z NI. Na tym etapie kierowano się zasadami „pracy na zasobach” (Klajs, Lipman, 2011) oraz „refleksji w działaniu”(Hamond, Haccou, 2011). III ETAP: Wspólne działania w przestrzeni społecznej i publicznej

Działania edukacyjne obu grup odbywały się w różnej przestrzeni społecznej (uniwersytet, muzea, teatr, ośrodki kultury). Ideą końcowego etapu było „wczuwanie się” w sytuację niepełnosprawnych rówieśników. Do zadań uczestników zajęć należała rozmowa o potrzebach kolegów i koleżanek, o tym, co możliwe i niemożliwe do wykonania. Efektem etapu było wzajemne poznanie się, rozumienie potrzeb własnych i innych. Na tym etapie stosowano zasadę „zaufania i autentyczności”. 
Rycina 1. Etapy zajęć edukacyjnych z przedsiębiorczości. Od lewej: komunikacja interpersonalna, trening współpracy, działania w przestrzeni publicznej

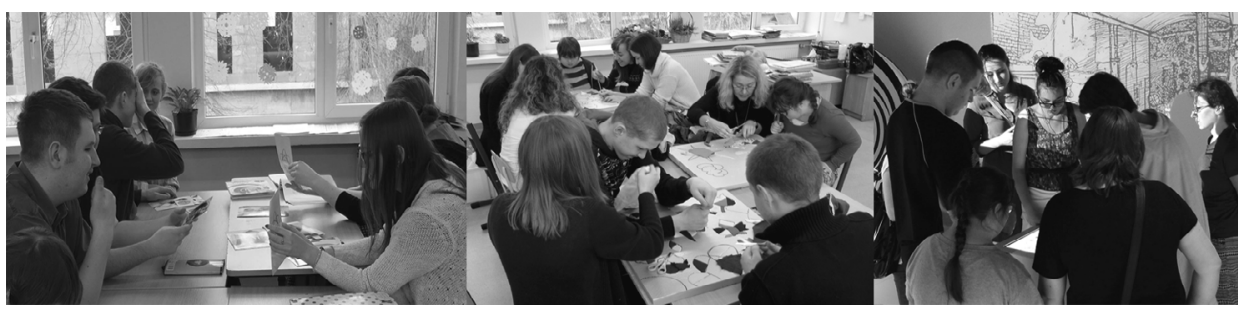

Źródło: materiały własne autorów

\section{Podsumowanie}

Aktywność zawodowa jest istotnym elementem w życiu każdego człowieka, także osoby niepełnosprawnej. Stanowi podstawowe źródło utrzymania, stanowiąc fundamentalny środek zaspokajania potrzeb. Wspiera rozwój osobowości człowieka oraz stymuluje jego aktywność, w konsekwencji wzmacnia poczucie własnej wartości. W tym ujęciu osoby $\mathrm{z}$ niepełnosprawnością stanowią w Polsce jedną z grup społeczno-ekonomicznych o najniższym wskaźniku zatrudnienia, co budzi sporo obaw (Frączek, 2003).

Aktywność zawodowa w życiu osób z niepełnosprawnością jest czynnikiem integrującym tę grupę z pozostałą częścią społeczeństwa. Osoby niepełnosprawne, nim zaistnieją na rynku pracy, muszą przezwyciężyć wiele barier - muszą wyjść z domu, przemieścić się, zdobyć wiedzę, kompetencje (Woźniak, 2007). Według J. Jerg (za: Szafranek, Halicki, 2016), warto wypracować takie podejście względem osób niepełnosprawnych, które pozwoli we wszystkich dziedzinach życia przestrzegać zasady równości szans. Ze względu na różnorodność i specyfikę funkcjonowania osób z niepełnosprawnościami wszelkie działania inkluzyjne nie powinny być uniwersalne, gdyż ta grupa ze względu na swoją biografię i charakterystykę wymaga inicjatyw kreatywnych odbiegających od klasycznych rozwiązań.

Konieczność wyrównywania szans osób niepełnosprawnych jest podkreślana zarówno w polskich aktach prawnych, jak i w prawodawstwie międzynarodowym. Zwraca się uwagę na możliwości korzystania przez niepełnosprawne jednostki z wszelkich przysługujących im praw. Korzyścią z podjętej aktywności zawodowej jest przełamywanie monotonii, poczucie samorealizacji oraz realnej przynależności do społeczeństwa.

Aktywizacja zawodowa, zatrudnienie wspomagane powinny być popularyzowane wśród potencjalnych pracowników, czyli osób z wszelkiego rodzaju dysfunkcjami, ale przede wszystkim - wśród pracodawców (Włodarska-Zoła, 2007).

Zaprezentowane wyniki badań, zaproponowany model edukacji przedsiębiorczości oraz przegląd literatury prowadzą do następujących wniosków:

1. Dla poprawy jakości funkcjonowania w społeczeństwie osób niepełnosprawnych intelektualnie szczególne znaczenie mają interakcje personalne oraz możliwość udziału w życiu społecznym, dlatego ważne jest danie szansy osobom niepełnosprawnym intelektualnie na pokazanie swych umiejętności rówieśnikom, by czuli się przydatni dla społeczeństwa.

2. Popularyzacja i rozpowszechnianie praktyk zawodowych $\mathrm{z}$ osobami niepełnosprawnymi intelektualnie, tak aby nauczyć kontaktów, relacji, potencjału, zniwelować strach i obawy. 
3. Dążyć do „oswojenia” niepełnosprawności. Potencjalni przyszli przedsiębiorcy (studenci i studentki) jeszcze przed założeniem własnej działalności dzięki wspólnym kontaktom winni uświadomić sobie potencjał zawodowy osób z niepełnosprawnością.

4. Podczas szkoleń dla pracodawców należy zwrócić uwagę na możliwości pracy osób niepełnosprawnych intelektualnie, nie tylko od strony ulg i udogodnień, ale też od strony potencjału zawodowego.

5. Pracodawcy winni przejść szkolenia oraz rozmawiać, motywować niepełnosprawnych intelektualnie i rozumieć ich potrzeby.

Literatura

References

Abramowska, B.E., Tłoczowska, D. (2007). Nauka i praca osób z niepełnosprawnościq intelektualną. Kołobrzeg: PSOUU. Pozyskano z: http://niepelnosprawni.gov.pl/container/publikacje/edukacja/ nauka\%20i\%20praca\%20osob\%20z\%20niepelnosprawnoscia\%20intelektualna.pdf

Atlas dobrych praktyk inkluzji społecznej i zawodowej. (2011). Warszawa: FISE na zlecenie FEBEA. Pozyskano z: http://www.ngo.pl/files/wiadomosci.ngo.pl/public/korespondenci/portal_ekonomiaspoleczna/AE.pdf

Babbie, E. (2007). Badania społeczne w praktyce. Warszawa: Wydawnictwo PWN.

Burgea, P., Ouellette-Kuntz, H., Lysagh, R. (2007). Public views on employment of people with intellectual disabilities. Journal of Vocational Rehabilitation, 26, 29-37. Pozyskano z: https://pdfs.semanticscholar.org/bf81/f7f482d523c38bf24fc12189fa1bdc269197.pdf

Cieślik, J. (2014). Przedsiębiorczość polityka rozwój. Warszawa: Wydawnictwo Akademickie Sedno.

Diament, M. (2015, 21 kwietnia). Program Looks to Turn People with Disabilities into Entrepreneurs. Pozyskano z: https://www.disabilityscoop.com/2015/04/21/program-entrepreneurs/20233/

Entrepreneurship Education (2018). European Commission. Pozyskano z: https://ec.europa.eu/growth/ smes/promoting-entrepreneurship/support/education_en

Europejska Unia Zatrudnienia Wspomaganego. Broszura informacyjna i standardy jakości. (2013). Warszawa: Polskie Forum Osób Niepełnosprawnych. Pozyskano z: https://www.pfon.org/images/ dodatki/20131114_broszura.pdf

Frączek, P. (2003). Determinanty aktywności osób niepełnosprawnych na rynku pracy. Polityka Spoteczna, 11/12, 10-14.

GUS. (2012). Osoby niepetnosprawne na rynku pracy w 2011 r. Warszawa: Pozyskano z: http://stat.gov. $\mathrm{pl} /$ obszary-tematyczne/rynek-pracy/opracowania/osoby-niepelnosprawne-na-rynku-pracy-w-2011-r-,5,1.html

Hamond, B., Haccou, R. (2013). Zdobywanie i ewaluacja kompetencji społecznych. Projekt ATLAS. Warszawa: PFON. Pozyskano z: https://www.pfon.org/images/dodatki/20131114_kompetencje.pdf

Jan Paweł II. (1981). Encyklika: O pracy ludzkiej Laborem Exercens. Castel Gandolfo. Pozyskano z: http:// www.opoka.org.pl/biblioteka/W/WP/jan_pawel_ii/encykliki/laborem.html

Klajs, K., Lipman, L. (2011). Terapia Ericksonowska. W: L. Grzesiuk, H. Suszek (red.), Psychoterapia. Szkoly i metody. Podręcznik Akademicki. Warszawa: ENETEIA, 283-297.

Kościelska, M. (1984). Upośledzenie umysłowe a rozwój społeczny. Warszawa: Wydawnictwo PWN.

Kościelska, M. (1995). Oblicza upośledzenia. Warszawa: Wydawnictwo PWN.

Mstowski, A. (2019, 10 stycznia). Centrum DZWONI - aktywizacja zawodowa osób niepetnosprawnych. Pozyskano z: http://inkubator.powiat.bedzin.pl/?p = 2124

Ministerstwo Rodziny, Pracy i Polityki Społecznej. (2018). Osoby niepelnosprawne na rynku pracy. Warszawa: Pozyskano z: http://www.niepelnosprawni.gov.pl/container/niepelnosprawnosc-w-liczbach/rynek-pracy/Osoby\%20niepelnosprawne\%20na\%20rynku\%20pracy.pdf 
GUS. (2017). Oświata i wychowanie w roku szkolnym 2016/2017. Warszawa - Wrocław. Pozyskano z: http://stat.gov.pl/obszary-tematyczne/edukacja/edukacja/oswiata-i-wychowanie-w-roku-szkolnym-20162017,1,12.html

Rymsza, M. (2013). Aktywizacja w polityce społecznej. W stronę rekonstrukcji europejskich welfare states? Warszawa: Instytut Filozofii i Socjologii Polskiej Akademii Nauk.

Ryś, G. (2018, 16 kwietnia). Wystąpienie abpa Grzegorza Rysia otwierające konferencję „Polonia Restituta” pod hasłem: Praca - Przedsiębiorczość - Społeczna Gospodarka Rynkowa. Pozyskano z: https://www.youtube.com/watch?reload $=9 \& v=$ QjLv7khRCik

Szafranek, A., Halicki, J. (2016). Wybrane aspekty inkluzji społecznej. W: M. Halicka, J. Halicki, K. Czykiera (red.), Niepetnosprawność. Poznać, przeżyć, zrozumieć. Białystok: Wydawnictwo Uniwersytetu w Białymstoku, 151-164.

Urbańska, K. (2013; 2019, 10 marca). Praca i zatrudnienie osób z niepetnosprawnościa intelektualną. Pozyskano z: http://www.ocwip.pl/informacje/wszystkie/zobacz/Praca-i-zatrudnienie-osob-zniepelnosprawnoscia-intelektualna

Yang, A. (2016; 2019, 10 marca). Why Entrepreneurship Education Does Not Work. Pozyskano z: https:// www.forbes.com/sites/andrewyang/2016/02/25/entrepreneurship-education-does-not-work

Vornholt, K., Villotti, P., Muschalla, B., Bauer, J., Colella, A., Zijlstra, F., Van Ruitenbeek, G., Uitdewilligen, S., Corbière, M. (2018). Disability and employment - overview and highlights. European Journal of Work and Organizational Psychology, 27(1), 40-55.

Wapiennik, E. (2005). Prawa osób z niepetnosprawnościa intelektualną. Dostęp do edukacji i zatrudnienia. Raport 2005. Warszawa: Open Society Institute, PSOUU. Pozyskano z: https://psoni.org.pl/ wp-content/uploads/2015/09/Report_ID_PolishVersion.pdf

Włodarska-Zoła, L. (2017; 2018, 17 stycznia). Aktywność zawodowa jako forma rehabilitacji osób niepełnosprawnych. Edukacja - Technika - Informatyka, 2(20). Pozyskano z: http://www.eti.rzeszow. pl/docs/ETI_7_2.pdf

Woźniak, Z. (2007). Główne bariery aktywności zawodowej osób z ograniczoną sprawnością. W: A. Brzezińska, Z. Woźniak, K. Maj (red.), Osoby z ograniczoną sprawnościa na rynku pracy. Warszawa: Academica Wydawnictwo WSPW, 69-84.

Zaorska, M. (2017). Osoba z niepełnosprawnością na/w drodze aktywizacji zawodowej - wybrane problemy a realia współczesnej rzeczywistości społecznej. W: B. Antoszewska, I. Myśliwczyk (red.), Jest człowiek $z$ niepetnosprawnościq - pola refleksji. Poznań: Wydawnictwo naukowe SILVA RERUM, 37-48.

Małgorzata Pietrzak, dr, starszy wykładowca w Instytucie Geografii i Gospodarki Przestrzennej Uniwersytetu Jagiellońskiego. Pedagog specjalny - oligofrenopedagog. Autorka publikacji z zakresu wdrażania teorii konektywizmu i teorii konstruktywistycznej w kształceniu przyrodniczym, z wykorzystaniem chmury internetowej i ICT w zajęciach kameralnych, terenowych i laboratoryjnych. Twórczyni idei kształcenia transmedialnego w naukach przyrodniczych, autorka edukacyjnego filmu transmedialnego o Krakowie.

Małgorzata Pietrzak, PhD, senior lecturer - Jagiellonian University, Institute of Geography and Spatial Management. Special educator - oligophrenopedagogue. Author of publications on the implementation of connectivism theory and constructivism in environmental education with the use of Internet Cloud and ICT in classroom, field and laboratory teaching. Creator of the idea of transmedia education in environmental sciences. Author of transmedia education film about Krakow.

ORCID: 0000-0002-7892-6503

\section{Adres/Address:}

Uniwersytet Jagielloński

Instytut Geografii i Gospodarki Przestrzennej

ul. Gronostajowa 7

30-387 Kraków, Polska

e-mail: malgorzata.pietrzak@uj.edu.pl 
Ewelina Sobocha, dr nauk o zdrowiu, adiunkt w Instytucie Pedagogiki Specjalnej Uniwersytetu Pedagogicznego im. Komisji Edukacji Narodowej w Krakowie, pedagog specjalny - oligofrenopedagog - i edukator seksualny. Ma doświadczenie w pracy z dziećmi, młodzieżą i dorosłymi z głębszą i głęboką niepełnosprawnością intelektualną. Jej zainteresowania naukowe to: funkcjonowanie psychospołeczne, dorosłość i starość osób z niepełnosprawnością intelektualną, seksualność osób $\mathrm{z}$ niepełnosprawnością intelektualną, zagadnienia związane z komunikacją i budowaniem relacji.

Ewelina Sobocha PhD, assistant professor in the Institute of Special Education at the Pedagogical University of Krakow, special educator and sex educator. She has experience in working with children, youth and adults with deeper and deep intellectual disabilities. Research interests: psychosocial functioning, adulthood and old age of people with intellectual disabilities, sexuality of people with intellectual disabilities, issues related to communication and building relationships.

ORCID: 0000-0003-1184-5167

\section{Adres/Address:}

Uniwersytet Pedagogiczny im. Komisji Edukacji Narodowej

Katedra Andragogiki Specjalnej

Instytut Pedagogiki Specjalnej

ul. Ingardena 4

30-060 Kraków, Polska

e-mail: ewelina.sobocha@up.krakow.pl 